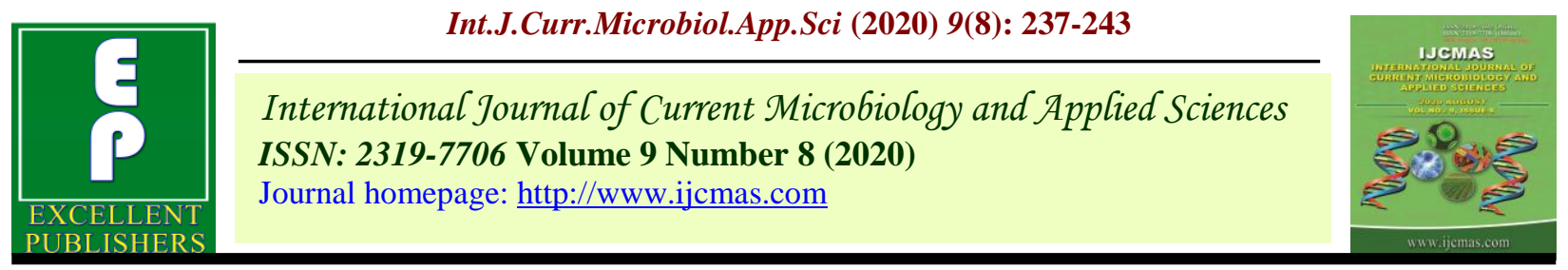

Original Research Article

https://doi.org/10.20546/ijcmas.2020.908.027

\title{
Reaction of Hill Khadia Tribe towards Developmental Activities Undertaken by Hkmda: A Study on Mayurbhanj District of Odisha, India
}

\author{
R. Mohanta*, R.S. Panigrahi, B.P. Mohapatra and B. Parasar \\ Department of Extension Education, College of Agril., OUAT, Bhubaneswar, Odisha, India \\ *Corresponding author
}

\begin{tabular}{|l|}
\hline Ke y w o r d s \\
Particularly \\
Vulnerable Tribal \\
Groups (PVTG), \\
Hill-Khadia, \\
HKMDA, Micro \\
project, Tribes in \\
Mayurbhanj
\end{tabular}

\section{A B S T R A C T}

The state of Odisha has multifariousness of tribal populations. The shining cultural heritage of tribal's of Odisha has made the state culturally gorgeous. Out of 62 tribes of Odisha, 13 tribes are considered as Particularly Vulnerable Tribal Groups (PVTG) and Hill Khadia is one amongst the 13. The majority of Khadia population is found in Karanjia and Jashipur blocks of Mayurbhanj district of Odisha. The main source of livelihood of Khadia tribe is farming, gathering of minor forest product, labour on daily wages. Fishing, hunting and animal husbandry are practiced as subsidiary occupations. HKMDA (Hill- Khadia \& Mankirdia Development Agency) has been working since 1987 for all round development of Hill-Khadia population of 18 villages. The HKMDA Micro Project is operating for the holistic development of Hill-Khadia including implementation of economic development programmes to raise their standard of living and to ensure quality of life. HKMDA has implemented various developmental activities for overall development of Hill Khadia people. To assess the reaction of Khadia people towards developmental activities a study was conducted in 8 villages of two blocks of Mayurbhanj district. A sample of 240 respondents was selected randomly. The pre-tested structured interview schedule was used to collect data personally. The collected data were processed, tabulated and analysed by using frequency, percentage, mean score, rank, etc.

\section{Introduction}

India is a welfare state committed to growth with social justice. Accordingly, eradication of poverty and raising the standard of living of the weaker sections of the population has been the most important objectives of India's economic planning. A section of India's population has been classified under the category called "Tribes"/ "Scheduled Tribes". There are around 645 distinct tribes in India.Of all the states of India, Odisha has the largest number of tribes as many as 62 types, of whom 13 communities are considered as Particularly Vulnerable Tribal Groups (PVTGs), and are being given special 
treatment. The Khadia are one of the largest indigenous ethnic groups of India. HKMDA is a micro project working since 1987 for all round development of Hill Khadia tribe.

The term "development" indicates the overall improvement of the quality of life. However, development in tribal regions has remained a challenge since time immemorial. The anthropological school of thought in reference to tribal development for tribal communities should be along the lines of their genius and that programmes implemented in tribal areas should have a 'tribal touch' or 'tribal bias' (Taradatt, 2001). Nevertheless, the battle of isolation and assimilation has affected tribal communities, thus obstructing the implementation of tribal development programmes. It was understood that the progress of social development can be observed in the form of empowerment, equitable distribution of income and wealth or in the broader context of socialization of natural resources, which can be possible only with the involvement of tribes in project formulation and implementation by working through their traditional system. The present tribal development process gives a completely different scenario; instead of involving tribes in the planning and implementation of developmental programs, they are rather blamed for the failure of developmental programs and schemes.

Although central and state government has introduced an immense number of programs and schemes, but in reality they have failed to reach the targeted population in many ways. Government has introduced many programs for development of Hill-Khadia people through HKMDA and to assess the reaction of the people towards those developmental programs, another objective was designed and data collected from the respondents on three point scale were analyzed and discussed in this section.

\section{Materials and Methods}

The present study was conducted in Jashipur and Karanjia blocks of Mayurbhanj district of Odisha selected purposively. Eight villages, 4 from each block namely Biunria, Batatainsira, Batpalsa and Kendumundi from Karanjia block and Kiajhari, Kapand, Matiagarh and Gudgudia from Jashipur block were selected randomly. A sample size of 240 respondents from eight villages at random was kept for the study. Different socio-economic variables like age, education, family size, family type, cosmopoliteness, social participation, extension participation, mass media exposure were measured with the help of a three-point interval scale and assigned scores of 3,2, 1 respectively. A structured interview schedule was developed and pre-tested on non-sampled respondents. Personal interview was made with individual respondents by the investigator to collect information. The data were processed, tabulated and analysed by employing suitable statistical methods such as frequency, percentage, mean score and rank order etc.

\section{Results and Discussion}

\section{Accessibility}

Accessibility means the quality of being able to be reached or entered, or easy to approach, easy to obtain. Undertaking various developmental programs has no meaning unless the respondents have accessibility to these programs. The data collected from the respondents on scale point of easy access, some access, no access have been analyzed with score value 3,2 and 1 respectively and presented in the table.1.

As observed from the table.2, accessibility of respondents towards education occupies rank I (3) followed by infrastructure support which occupies rank II (2.67), drinking water facility 
occupies rank III (2.59) and other social amenities, rank IV (2.58). Poor accessibility towards activities like vocational activities having rank VIII (1.75), market facility occupies rank IX (1.33) and socio-cultural activities occupies rank-X (1). Mixed response found in activities like accessibility towards farm activity (rank-V, 2.33), health care and sanitation (rank-V, 2.33), credit \& finance (rank-VI, 2.24) and irrigation (rankVII, 1.89).

\section{Involvement}

Active involvement of the people in various activities increases their interest, knowledge and skill competency in application of the changed practice. The study attempted to assess the reaction of Khadia people towards involvement in various developmental activities undertaken by HKMDA. The result obtained from analyzing the collected data represented in the table. 3

Table.1 Accessibility of respondents towards various developmental activities

\begin{tabular}{|l|l|l|l|l|l|l|}
\hline $\begin{array}{l}\text { SI } \\
\text { No }\end{array}$ & Statement & $\begin{array}{l}\text { Easy } \\
\text { Access }\end{array}$ & $\begin{array}{l}\text { Some } \\
\text { Access }\end{array}$ & No Access & $\begin{array}{l}\text { Mean } \\
\text { Score }\end{array}$ & Rank \\
\hline $\mathbf{1}$ & Irrigation & $94(39.17)$ & $26(10.83)$ & $120(50.00)$ & 1.89 & VII \\
\hline $\mathbf{2}$ & Drinking water & $160(66.67)$ & $62(25.83)$ & $18(7.50)$ & 2.59 & III \\
\hline $\mathbf{3}$ & Farm activity & $98(40.83)$ & $122(50.84)$ & $20(8.33)$ & 2.33 & V \\
\hline $\mathbf{4}$ & $\begin{array}{l}\text { Healthcare and } \\
\text { sanitation }\end{array}$ & $98(40.83)$ & $124(51.67)$ & $18(7.50)$ & 2.33 & V \\
\hline $\mathbf{5}$ & Education & $240(100)$ & - & - & 3 & I \\
\hline $\mathbf{6}$ & Vocational activity & $18(7.50)$ & $144(60.00)$ & $78(32.50)$ & 1.75 & VIII \\
\hline $\mathbf{7}$ & Infrastructure support & $164(68.33)$ & $72(30.00)$ & $4(1.67)$ & 2.67 & II \\
\hline $\mathbf{8}$ & Socio-cultural activity & - & - & $240(100)$ & 1 & X \\
\hline $\mathbf{9}$ & Credit and finance & $92(38.33)$ & $114(47.50)$ & $34(14.17)$ & 2.24 & VI \\
\hline $\mathbf{1 0}$ & Market facility & $4(1.67)$ & $72(30.00)$ & $164(68.33)$ & 1.33 & IX \\
\hline $\mathbf{1 1}$ & Other social amenities & $144(60.00)$ & $90(37.50)$ & $6(2.50)$ & 2.58 & IV \\
\hline
\end{tabular}

Table.2 Involvement of people in different activities

\begin{tabular}{|l|l|l|l|l|l|l|}
\hline $\begin{array}{l}\text { SI } \\
\text { No }\end{array}$ & Activities & $\begin{array}{l}\text { Fully } \\
\text { Involved }\end{array}$ & $\begin{array}{l}\text { Partially } \\
\text { Involved }\end{array}$ & $\begin{array}{l}\text { Not } \\
\text { Involved }\end{array}$ & $\begin{array}{l}\text { Mean } \\
\text { Score }\end{array}$ & Rank \\
\hline $\mathbf{1}$ & Irrigation & $48(20.00)$ & $78(32.50)$ & $114(47.50)$ & 1.73 & X \\
\hline $\mathbf{2}$ & Drinking water & $121(50.42)$ & $119(49.58)$ & - & 2.50 & IV \\
\hline $\mathbf{3}$ & Farm activity & $84(35.00)$ & $138(57.50)$ & $18(7.50)$ & 2.28 & VI \\
\hline $\mathbf{4}$ & Healthcare and & $100(41.67)$ & $130(54.17)$ & $10(4.16)$ & 2.38 & V \\
& sanitation & & & & \\
\hline $\mathbf{5}$ & Education & $205(85.42)$ & $31(12.92)$ & $4(1.66)$ & 2.84 & I \\
\hline $\mathbf{6}$ & Vocational activity & $8(3.33)$ & $204(85.00)$ & $28(11.67)$ & 1.92 & VIII \\
\hline $\mathbf{7}$ & Infrastructure support & $175(72.92)$ & $65(27.08)$ & - & 2.73 & II \\
\hline $\mathbf{8}$ & Socio-cultural activity & $50(20.84)$ & $107(44.58)$ & $83(34.58)$ & 1.86 & IX \\
\hline $\mathbf{9}$ & Credit and finance & $37(15.42)$ & $69(28.75)$ & $134(55.83)$ & 1.60 & XI \\
\hline $\mathbf{1 0}$ & Market facility & $62(25.83)$ & $114(47.50)$ & $64(26.67)$ & 1.99 & VII \\
\hline $\mathbf{1 1}$ & Other social amenities & $194(80.83)$ & $20(8.33)$ & $26(10.83)$ & 2.70 & III \\
\hline
\end{tabular}


Table.3 Usability of various activities undertaken by HKMDA

\begin{tabular}{|l|l|l|l|l|l|l|}
\hline $\begin{array}{l}\text { SI } \\
\text { No }\end{array}$ & Activities & Usefull & $\begin{array}{l}\text { Somewhat } \\
\text { Useful }\end{array}$ & $\begin{array}{l}\text { Not } \\
\text { Useful }\end{array}$ & $\begin{array}{l}\text { Mean } \\
\text { Score }\end{array}$ & Rank \\
\hline $\mathbf{1}$ & Irrigation & $47(19.58)$ & $84(35.00)$ & $109(45.42)$ & 1.74 & IX \\
\hline $\mathbf{2}$ & Drinking water & $164(68.33)$ & $48(20.00)$ & $28(11.67)$ & 2.57 & IV \\
\hline $\mathbf{3}$ & Farm activity & $141(58.75)$ & $72(30.00)$ & $27(11.25)$ & 2.47 & VII \\
\hline $\mathbf{4}$ & Healthcare and sanitation & $135(56.25)$ & $101(42.08)$ & $4(1.67)$ & 2.55 & V \\
\hline $\mathbf{5}$ & Education & $226(94.17)$ & $14(5.83)$ & - & 2.94 & I \\
\hline $\mathbf{6}$ & Vocational activity & $130(54.17)$ & $96(40.00)$ & $14(5.83)$ & 2.48 & VI \\
\hline $\mathbf{7}$ & Infrastructure support & $189(78.75)$ & $51(21.25)$ & - & 2.79 & III \\
\hline $\mathbf{8}$ & Socio-cultural activity & $130(54.17)$ & $96(40.00)$ & $14(5.83)$ & 2.48 & VI \\
\hline $\mathbf{9}$ & Credit and finance & $44(18.33)$ & $100(41.67)$ & $96(40.00)$ & 1.78 & VIII \\
\hline $\mathbf{1 0}$ & Market facility & $22(9.17)$ & $106(44.17)$ & $112(46.66)$ & 1.63 & X \\
\hline $\mathbf{1 1}$ & Other social amenities & $205(85.42)$ & $35(14.58)$ & - & 2.85 & II \\
\hline
\end{tabular}

Table.4 Technological feasibility of various developmental activities undertaken by HKMDA

\begin{tabular}{|l|l|c|c|c|c|c|}
\hline $\begin{array}{l}\text { SI. } \\
\text { No }\end{array}$ & Statement & Feasible & $\begin{array}{c}\text { Somewhat } \\
\text { Feasible }\end{array}$ & $\begin{array}{c}\text { Not } \\
\text { Feasible }\end{array}$ & $\begin{array}{c}\text { Mean } \\
\text { Score }\end{array}$ & Rank \\
\hline $\mathbf{1}$ & Availability of irrigation facility & $78(32.5)$ & $66(27.50)$ & $96(40.00)$ & 1.93 & VII \\
\hline $\mathbf{2}$ & Drinking water facility for farm & $160(66.67)$ & $64(26.66)$ & $16(6.66)$ & 2.64 & III \\
\hline $\mathbf{3}$ & $\begin{array}{l}\text { Timely input supply for } \\
\text { activities }\end{array}$ & & & & & \\
\hline $\mathbf{4}$ & Health care and sanitation facility & $92(38.33)$ & $134(55.84)$ & $14(5.83)$ & 2.33 & IV \\
\hline $\mathbf{5}$ & Educational facility & $240(100)$ & - & - & 3 & I \\
\hline $\mathbf{6}$ & Infrastructural facility & $171(71.25)$ & $69(28.75)$ & - & 2.71 & II \\
\hline $\mathbf{7}$ & $\begin{array}{l}\text { Support for socio-cultural } \\
\text { activities for }\end{array}$ & - & $11(4.58)$ & $229(95.42)$ & 1.05 & IX \\
\hline $\mathbf{8}$ & Credit and finance facility & $92(38.33)$ & $96(40.00)$ & $52(21.67)$ & 2.17 & VI \\
\hline $\mathbf{9}$ & Marketing facility & $6(2.50)$ & $32(13.33)$ & $202(84.17)$ & 1.18 & VIII \\
\hline
\end{tabular}

Table.5 Credit and financial activity undertaken by HKMDA

\begin{tabular}{|l|l|c|c|c|c|c|}
\hline $\begin{array}{l}\text { SI } \\
\text { No. }\end{array}$ & Statement & $\begin{array}{c}\text { Strongly } \\
\text { Agree }\end{array}$ & Agree & Disagree & $\begin{array}{c}\text { Mean } \\
\text { Score }\end{array}$ & Rank \\
\hline $\mathbf{1}$ & Motivating for availing credit & $26(10.83)$ & $128(53.33)$ & $86(35.84)$ & 1.75 & V \\
\hline $\mathbf{2}$ & Facilitating credit support & $60(25.00)$ & $142(59.17)$ & $38(15.83)$ & 2.09 & III \\
\hline $\mathbf{3}$ & Liasoning with credit institute & $89(39.08)$ & $139(57.92)$ & $12(5.00)$ & 2.32 & I \\
\hline $\mathbf{4}$ & Subsidy facility & $35(14.58)$ & $197(82.08)$ & $8(3.34)$ & 2.11 & II \\
\hline $\mathbf{5}$ & Flexibility in fixing installment & $33(13.75)$ & $169(70.42)$ & $38(15.83)$ & 1.98 & IV \\
\hline $\mathbf{6}$ & $\begin{array}{l}\text { Act as guarantee in availing } \\
\text { credit }\end{array}$ & $31(12.92)$ & $173(72.08)$ & $36(15.00)$ & 1.98 & IV \\
\hline
\end{tabular}


Table.6 Reaction of respondents towards various service and supply provided by HKMDA

\begin{tabular}{|c|c|c|c|c|c|c|}
\hline $\begin{array}{l}\text { Sl } \\
\text { No. }\end{array}$ & Statement & $\begin{array}{l}\text { Strongly } \\
\text { Agree }\end{array}$ & Agree & Disagree & $\begin{array}{l}\text { Mean } \\
\text { Score }\end{array}$ & Rank \\
\hline 1 & $\begin{array}{l}\text { Training and orientation } \\
\text { programme for capacity } \\
\text { building }\end{array}$ & $44(18.33)$ & $130(54.17)$ & $66(27.50)$ & 1.91 & III \\
\hline 2 & Exposure visit & - & $81(33.75)$ & $159(66.25)$ & 1.34 & VI \\
\hline 3 & $\begin{array}{l}\text { Timely supply of seed and } \\
\text { planting material }\end{array}$ & $102(42.50)$ & $50(20.83)$ & $88(36.67)$ & 2.06 & II \\
\hline 4 & $\begin{array}{l}\text { Supply of chemical and } \\
\text { fertiliser }\end{array}$ & $92(38.33)$ & $144(60.00)$ & $4(1.67)$ & 2.37 & I \\
\hline 5 & Supply of poultry, goat etc. & $38(15.83)$ & $108(45.00)$ & $94(39.17)$ & 1.77 & IV \\
\hline 6 & $\begin{array}{l}\text { Regular supervision and } \\
\text { guidance }\end{array}$ & $10(4.17)$ & $160(66.66)$ & $70(29.17)$ & 1.75 & V \\
\hline
\end{tabular}

As depicted from the table.2 highest involvement of Khadia people was found in educational activity which occupies rankI(2.84), followed by infrastructure support having rank-II (2.73), other social amenities occupies rank-III (2.70), drinking water facility occupies rank-IV (MS-2.50,), health care and sanitation measure occupies rank-V (2.38), farm activity occupies rank-VI (2.28) etc. mixed response found regarding involvement in activities like marketing which occupies rank VII (1.99), vocational activity occupies rank VIII (1.92), socio cultural activity occupies rank IX (1.86). Lowest involvement found in activity like irrigation which occupies rank X (1.73) and credit \& financial activity occupies rank XI (1.6).

\section{Usability}

Implementation of various programmes has no use, if people does not adopt those or does not feel the usefulness of the programme. An attempt had been made to analyse the extent to which the respondents were using the facilities provided by HKMDA and up to what extent the facilities were useful to them. The data collected from the respondents on the scale point of useful, somewhat useful and not useful have been analysed with score value of 3,2 , and 1 respectively. The result obtained have been presented below

From the table. 3 highest usability found in educational activity having rank I (2.94) i.e. $94.17 \%$ of total respondents are using the educational facility because they feel the importance and usefulness of education similarly, other social amenities occupying rank II(2.85), infrastructure support occupying rank III(2.79), drinking water occupying rank IV(2.57), health care and sanitation occupying rank $\mathrm{V}(2.55)$, vocational activities\& socio cultural activities having rank VI (2.48), farm activities having rank VII (2.47). Lower usability found in case of market facility occupying rank-X (1.63), irrigation occupying rank-IX (1.74). Mixed response found in case of usability of credit and finance which occupies rank-VIII (1.78).

\section{Technological feasibility}

Technological feasibility is the measure of how well a proposed system or activity solves the problems and how it satisfies the requirements or needs of the respondents. An attempt was made to measure the feasibility of various technology or developmental 
activities undertaken by HKMDA. Data were collected from the respondents on the scale point of feasible, somewhat feasible, and not feasible with score value 3, 2, 1 respectively, and analysed as presented the table.4.

From the table.5 it was depicted that technological feasibility found highest in educational facility occupying rank-I(3), because all (children of age group 3-15) can easily access to school since HKMDA established 'gyana mandir' for the children of age group 3-5 years, educational complex with hostel accommodation for both boys and girls and also almost all khadia villages having primary school, also found good response towards technological feasibility of infrastructural facility which occupies rank- II (2.71), drinking water facility occupies rankIII(2.64), health care and sanitation occupies rank-IV(2.33), timely input supply for farm activity occupies rank- $\mathrm{V}(2.3)$, credit and finance facility occupies rank-VI(2.17). Poor response found in case of support for sociocultural activities which occupies rank- IX (1.5), market facility occupies rank- VIII (1.81), irrigation facility occupies rank-VII (1.93).

\section{Credit and finance}

To ensure production and productivity, recommended input should be applied. Khadia people are generally resource poor. Hence HKMDA undertaken various activities to facilitate credit and financial support. The reaction of respondents were collected, analysed and presented in the table. 6 .

From the table. 5 mixed reactions were found, however, liasoning with credit institute occupies rank I (2.32) subsidy facility by financial institute occupies rank II (2.11) followed by facilitating credit support with rank III(2.09). Reactions towards flexibility in fixing instalment, act as guarantee in availing credit, motivating for availing credit also quite good having mean rank IV(1.98), IV(1.98), and V(1.75) respectively, but these areas can be improved by motivating people to avail credit.

\section{Service and supply}

To improve the socio-economic status of HillKhadia people, HKMDA has provision for various service and supply to the khadia people. To know the reaction of respondents towards various service and supply provided by HKMDA, data were collected on the scale point of strongly agree, agree, disagree with score value 3,2,1 respectively. The data collected are analysed and presented in the table. 6

From the table.5 it was depicted that reaction of respondents towards supply of critical inputs such as chemical and fertilizer occupies rank I(2.37), supply of seed and planting material occupies rakn II(2.06) followed by training and orientation programme for capacity building having rankIII(1.91). Similarly, mixed response found in supply of poultry, goat etc. occupies rankIV(1.77) followed by regular supervision and guidance having rank-V(1.75) and poor response found regarding exposure visit for awareness and capacity building having rankVI (1.34).

From the study it was concluded that Khadia people get easy access to education i.e each and every respondent found the education easily accessible because HKMDA established Gyana Mandir and Educational Complex for free education of Khadia tribe for the age group of 3-15 years children. Respondents also found easy access to infrastructure support, drinking water facility and other social amenities. Similarly, respondents were expressed their difficulties in accessibility towards vocational activity, 
market linkage, socio-cultural activities and health care and sanitation. Regarding involvement in different developmental activities people were more involved in activities like education, infrastructure, other social amenities, drinking water facilities, health care and sanitation etc. and less involved in socio-cultural activities, irrigation activity and credit and financial activity. Regarding usability Khadia people feel more use full for them is education, other social amenities, infrastructure, drinking water facility, health care and sanitation, vocational activity and socio cultural activity. Regarding technological feasibility Khadia tribe found educational facility, infrastructure, drinking water facility and credit and finance facility as more feasible rather than other activities like marketing facility and support for sociocultural activity. Similarly, regarding credit and finance facilities positive responses were found in case of liasioning with credit institutes, subsidy facility \& facilitating credit support. Regarding various service and supply provided by HKMDA to Khadia people positive responses found in case of supply of critical inputs such as chemical fertilisers, seeds and planting materials etc. and mixed response found in activities like vocational training programmes, exposure visits etc.

Although HKMDA has implemented various developmental activities for all round development of Hill Khadia people still a lot has to be achieved for which a proper strategic plan need to be developed and implemented accordingly. For improving the living standard of Hill Khadia people more no of vocational activities and skill development trainings along with exposure visits need to be implemented for bridging the gap with main stream. Development programmes should be planned and implemented in such a manner that maximum benefit should be given to the community need. Hence, they can easily accept the programme and accommodate themselves within it.

\section{References}

Dash, J. (1998). Human ecology of foragers: a study of the Kharia (Savara), Ujia (Savara), and Birhor in Similipāl hills. New Delhi: Commonwealth.

Sinha, D. (1984). The hill Kharia of Purulia: a study on the impact of poverty on a hunting and gathering tribe. Calcutta: Anthropological Survey of India, Govt. of India.

Sahoo. M. (2013). Tribal Development: A Critical Analysis of Developmental Programmes on Mankirdia, a Particularly Vulnerable Tribal Group, in the Mayurbhanj District, Odisha., international journal of social and economic research.

Tudu, F. (2017). Socio-cultural History of Hill Kharia Tribe of Mayurbhanj district, Odisha, International Journal of Research.

Vidyarthi, L. P., and Upadhyay, V. S. (1980). The Kharia, then and now: a comparative study of Hill, Dhelki, and Dudh Kharia of the central-eastern region of India. New Delhi.

\section{How to cite this article:}

Mohanta, R., R.S. Panigrahi, B.P. Mohapatra and Parasar, B. 2020. Reaction of Hill Khadia Tribe towards Developmental Activities Undertaken by Hkmda: A Study on Mayurbhanj District of Odisha, India. Int.J.Curr.Microbiol.App.Sci. 9(08): 237-243. doi: https://doi.org/10.20546/ijcmas.2020.908.027 